\title{
Article
}

\section{Visualizing a Society on the Brink: Gaza and Hebron}

\author{
Bratchford, Gary
}

Available at http://clok.uclan.ac.uk/15751/

Bratchford, Gary (2014) Visualizing a Society on the Brink: Gaza and Hebron. Journal of Arab and Muslim Media Research, 7 (2\&3). pp. 145-162. ISSN 17519411

It is advisable to refer to the publisher's version if you intend to cite from the work. http://dx.doi.org/10.1386/jammr.7.2-3.145_1

For more information about UCLan's research in this area go to http://www.uclan.ac.uk/researchgroups/ and search for < name of research Group>.

For information about Research generally at UCLan please go to http://www.uclan.ac.uk/research/

All outputs in CLoK are protected by Intellectual Property Rights law, including Copyright law. Copyright, IPR and Moral Rights for the works on this site are retained by the individual authors and/or other copyright owners. Terms and conditions for use of this material are defined in the policies page.

\section{CLoK}

Central Lancashire online Knowledge www.clok.uclan.ac.uk 


\title{
Visualizing a society on the brink: Gaza and Hebron
}

Gary Bratchford, Manchester Metropolitan University

\begin{abstract}
This article begins with Operation Protective Edge, the Israeli military operation against Gaza during the summer months of 2014. This article examines the Israeli use of language and the emphasis on terror, trauma and victimhood as vehicles upon which to mobilize and justify its multi-narrative, collective punishment of the Palestinian. I will identify how this use of language helps to frame Israel's actions as democratic by acting in defence, a process articulated throughout previous military operations. Such a process is implicit within the dominant political imaginary that constitutes much of the popular discourse that shapes the Israeli relationship with the Palestinian. Thereafter, I will highlight how a number of documentary photographers have sought to challenge the political visibilities related to the Israeli Palestine conflict by attempting to visualize the ongoing 'catastrophization of Gaza' before switching my attention to Hebron and the work of the photography collective, Activestills.
\end{abstract}

\section{Keywords}

Operation Protective Edge

visibility

photography 
politics

Occupied Palestinian Territories

Israel

\section{Introduction}

Go, go, go, said the bird: human kind cannot bear very much reality. Time past and time future, what might have been and what has been point to one end, which is always present.

These, the last lines of the opening paragraph of T. S. Eliot's 'Burnt Norton', were prescient as I sat thinking about this article. For the Palestinian in the Occupied Territories, time past and time future do indeed point to an end that is always present: the occupation. Since the establishment of the Green Line in 1967, Palestinians within the Occupied Territories have been subject to a temporality that is open-ended. ${ }^{1}$ The bird of Eliot's poem acts as the narrator of truth within the imaginative space of Eliot's rose garden. The tweet of Eliot's bird, much like the tweets that flooded the social media platform Twitter, drew our attention to a reality that often became hard to bear. The tweet became constitutive of how the visibilities of war in recent years are mediated, attesting to how technology and the journalistic environment undergo change in form and function. Here one can look at David Campbell's (2009) analysis 
of the Israeli incursion into Gaza during 2009 where it can be suggested that social media and citizen journalism helped to construct a public visibility of a social reality (Couldry 2000) that would otherwise remain largely unseen were it not for those on the ground, in the immediacy of the event. ${ }^{2}$ In what follows, this article will seek to outline some of the issues related to the production of visibilities in Gaza and the West Bank in response to the 2014 bombardment of Gaza and later the effects and challenges of visualizing the regime-made violence of the occupation. After exploring the rhetorical approach taken by Israel in the build-up to the bombardment of Gaza, I will shift my attention to the analysis of the documentary photography of Gianluca Panella and the photography collective, Activestills. By employing Jacque Ranciere's notion that 'politics is first of all a battle about perceptible and sensible material'(Guénoun, and Kavanagh 2000, 11), I will explore how both Panella and Activestills seek to reconfigure the distribution of the sensible in relation to what is visible and invisible, sayable and unsayable. As power is closely aligned with visibility, I will argue that both Panella and Activestills reconfigure the distribution of the sensible. In both cases, I argue, we are invited to see the effects of the occupation through a new set of configurations, in doing so, thereby altering the spectatorial expectation of the viewer and our understanding of the occupation in a day-to-day context.

\section{The in/visibility of the occupation}

On the 8 July 2014, Israel launched Operation Protective-Edge, a 50-day fully fledged military attack upon the Gaza Strip that included bombardment launched from the sky, sea and the land combined with a short ground incursion. Operation 
Protective Edge, or Strong Cliff in Hebrew, concluded on 26 August 2014 after an Egyptian-brokered ceasefire. The subsequent 50-day barrage resulted in the death of 2100 Palestinians and one 'other'. ${ }^{3}$ As of 5 August a report from Amnesty International stated that 86 per cent of the Palestinian losses within the Gaza Strip were civilians. ${ }^{4}$ The report, which drew data from the UN Office for the Coordination of Humanitarian Affairs (OCHA), also noted that more than 9400 people had been injured, many of them seriously, while an estimated 485,000 people across the Gaza Strip had been displaced. Such figures attest to the military wrath that besieged the Palestinian enclave, while the Israeli loss of life came in at 66, all of whom were Israeli Defense Force (IDF) combatants. The 'displacement of the displaced' points to a tragedy that is almost beyond visuality; however, interesting and informative infographics, maps and videos helped to visualize the scale of the destruction. ${ }^{5}$ One such video from the independent Palestinian production company MediaTown depicts the devastated urban topology of Al-Shejaiya, a suburb of Gaza City, which between 19 and 20 July 2014 underwent one of the heaviest bombardments of the operation. ${ }^{6}$ The haunting footage shot from a drone and uploaded to YouTube invites the spectator to see the scale of the damage. The 50-second clip surveys the wounded landscape, adding to the multiple optics of war visibilities and mediations, which contribute to the burgeoning archive of visual material related to Gaza. Techniques like this help to shift how the visual is used, marking what Meg Mclagan noted as a move from 'documentation through photojournalism to a means of strategic communication' (2007). This means of producing counter visibilities promotes a widening of the space in which politics can be conceived, performed and seen: visibilities that challenge the attempts by the Israeli state to control the visual field as was the case in 2009. 
According to Ranciere, 'politics is a question of aesthetics, a matter of appearances' (1999: 74). In Israel-Palestine, regimes of visibility and the relationship between politics and aesthetics concerning what is possible to see and how that visibility is constructed are closely aligned with the distribution of power. In an asymmetric context, such as the occupation of Palestinian Territories by the Israeli State, order is imposed upon the inhabitants by means of military force, changing them from citizen into subject. As such, the construct and mediation of visibilities within Gaza and the West Bank are always contingent on how political action is framed and made visible. While the conditions of both geographies differ in how they are controlled, the former is remotely or 'digitally occupied' by Israel (Tawil-Souri 2014) and is without any permanent Israeli presence, the latter is managed through a combination of administrative and military rule. Yet, dominating the field of visibility, specifically within a security discourse, is the notion that Israelis are neighbouring a society that is immersed in a pathological culture of violence. This neighbouring 'culture of violence' goes some way to explaining the Israeli hostility towards the immediate and longterm effect of their most recent military operation.

Close to Hebron on the 15 June 2014, the kidnapping of three Jewish Israeli teenagers sparked a multi-narrative justification for what became Operation Protective Edge. Responding to the kidnapping and discovery of the three dead Israelis, the IDF prepared for a manhunt of the Palestinian city, blocking the main access routes to the city with concrete blocks and setting up a large number of checkpoints(Levy, 2014). In the wake of the kidnappings, Israeli Prime Minister Benjamin Netanyahu was quick to suggest that Hamas was responsible, with the IDF official blog claiming 'Hamas terrorists kidnapped three Israeli teenagers in Judea and Samaria... meanwhile Palestinians have been calling for further abduction' (emphasis added). ${ }^{7}$ 
The use of the term 'Palestinians' generalizes the population, marking one of the first of many instances where the Israeli government utilized language to make a collective distinction between 'us and them' in the run up to their military operation, mobilizing the imaginative political binaries of 'good and evil', 'democratic and terror-state'. Thereafter, the focus-shifted west to the Gaza strip where the IDF responded to Hamas rocket attacks fired into Israel. Drawing comparisons with the Blitz, Israeli Prime Minister Benjamin Netanyahu stated that 'Israel is undergoing a similar bombardment', claiming that 'there's only been one other instance where a democracy has been rocketed and pelleted with these projectiles of death, and that's Britain during World War Two' (Spencer, 2014). Finally, on 17 July Israel invaded Gaza with a ground incursion aimed at destroying the 'terror tunnels' that linked Gaza with Israel. However, the original Israeli statement that Hamas was responsible for the kidnapping was subsequently proven unfounded; Israel had already shifted attention to a victim and security discourse that justified their ensuing actions. The latter typifies what Simon Faulkner (2009) refers to as the 'political imaginary' of the occupation that affects both the political and social aspect of Israeli culture. Over the three narratives that underpinned each Israeli military action, culminating in Operation Protective Edge, the use of emotive language that drew on a discourse of terror, defense and democracy in opposition to a neighbouring terror state helped to anchor the rhetoric and action of the IDF and Israeli state. As Dr Mads Gilbert noted, when interviewed on the BBC's political show HARtalk (2014) Israel takes language hostage. ${ }^{8}$

The apathetic nature of the Palestinian is born from a long-established perceptible reality that is organized around a fundamental opposition between Israelis and Palestinians living in the occupied territories that obfuscates the nature of the 
occupation as an occupation. As such, Israel is often seen to be at war with Gaza; the connotations and popular mediations of which asserts that such a position is purely defensive. The political imaginary functions on a number of levels, first the designation of Gaza as a 'hostile entity' prefigures Gaza and Hamas as the perpetrator, ensuring that Israel is often a victim.

The tunnels are one such instance where the long tentacle of terror reaches deep beneath the civil society of Israel. Second, in response to the kidnapping, the rocket attacks and the 'terror tunnels' help Israel frame their conduct in 'response to' Palestinian action, helping to disassociate itself from the wider geopolitical frame of the long-standing occupation of Palestinian territory. This point has been noted by Craig Jones who asserts that Israel's visual representation of the assault on Gaza during 2008 can be summarized by a simple typology: 'it's their fault, not ours' and its corollary: 'they started it', thus recycling old tropes of victimhood (2011: 7). The Israeli Defense cabinet officially declared the creation of Gaza as a 'hostile enemy' in 2007, thus feeding into the political imagination of cultural 'othering', through various practices, including designating Gaza and all those which inhabit the political space as 'hostile'. Such a representation helps create a conceptual framework that Lisa Bhungalia (2010) argues is based upon 'an ontological distinction of "us" and "them", a distinction clearly articulated by the IDF tweet on the 15 July, in response to the kidnapping. The threat of Gaza is also affirmed through the rhetorical discourse used by popular Israeli figures such as the historian, Benny Morris, who claimed in the Israeli newspaper Ha'aretz, during an interview in 2004, a need for the Separation Wall in the West Bank, because it 'quells the revenge culture central in the Arab tribal customs with no moral inhibitions' (Shavit 2004). This sentiment is not a marginal 
reaction within the Israeli public sphere, more recently, on the 28 July 2014, Moshe Feiglin, Deputy Speaker for the Israeli Knesset and member of the Prime Minister's Likud party, remarked that 'the only innocents in Gaza are the IDF Soldiers' while Gazan's were 'savages in the desert'. Furthermore, on the 4 August he posted to his verified Facebook account a desire for electricity and water supply to Gaza to be disconnected before being 'shelled with maximum fire power' (Reilly 2014). The calls for the elimination of Gaza, while extreme, are consistent with a narrative that Gaza is first and foremost a hostile space. Crucially, as Jones notes, Israel is always already the victim, and Gaza and Hamas are always already the perpetrators (2011: 8). If Gaza is the aggressor then accordingly they started it; Israeli action is prefigured as a response to (rather than an instigation of) violence. Moreover, the language of war is just as significant as controlling the image that is incumbent with it. While political rhetoric and press conferences reiterate a symmetric engagement, a conflict that responds to a 'hostile enemy', the media management of the operation begins with the name, specifically the 'English translation' in this instance, Protective Edge (Arnaout 2014). The connotative rhetoric of defense is assimilated into the topology of the space in question. However, the figures tell a different story; in 2008 through to early 2009 Operation Cast Lead resulted in 1391 Palestinian deaths, while in 2012 operation Pillar of Defence 167 Palestinian lives were lost. ${ }^{9}$ Yet the representational framing of such loss is lessened due to the visual economy ${ }^{10}$ of the Palestinian image because what constitutes an 'eligible' human life reflects, at base, configurations of sovereignty, which Ophir and Hanafi (in Hanafi 2009) refer to as 'inclusive exclusion'. Delineating who or what is included in (or excluded from) the juridicalpolitical realm - as a terror state, the Gazan, and more broadly the Palestinian, becomes an apathetic entity through Israeli political discourse. In doing so, an 
interdependency and understanding of Israel existence is built on wars that justify their actions based on democracy and defence, and shape how we read and accept the images and rhetoric they produce. As Slavoj Žižek has pointed out, actions taken on the part of Palestinians are prefigured as 'acts of terror', and cited as 'proof' that Israel is, in fact, dealing with terrorists, and thus their image is affected as such and any such loss of life, including civilian loss, is masked to fit the narrative of defense and the battle against terror.

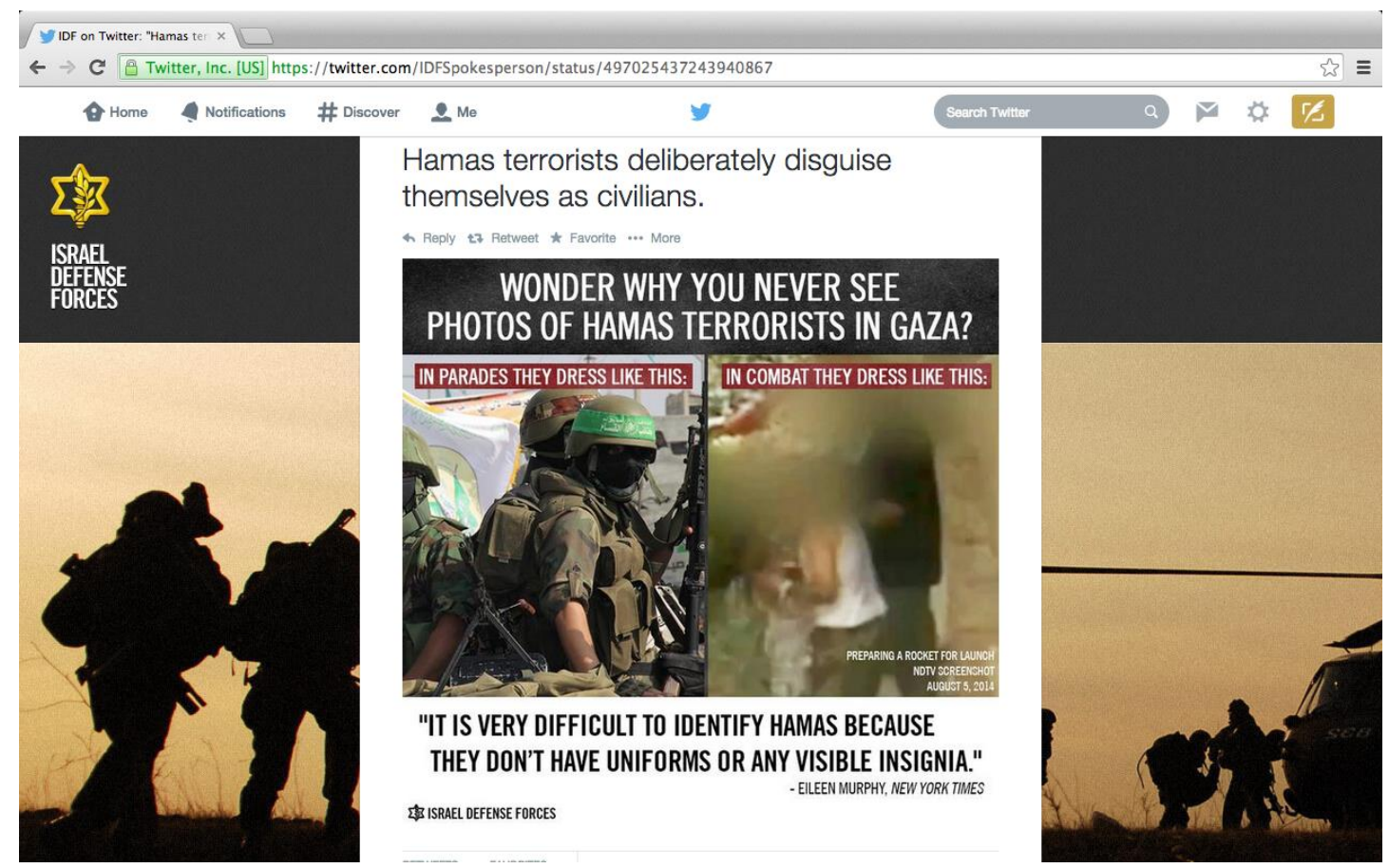

Figure 1: IDF Twitter account ‘@IDFSpokesperson' image from Operation Protective Edge: the invisible enemy of Hamas - the tweet was retweeted 784 times with 354 'favourites'.

This paradox, Žižek argues, "is inscribed into the very notion of a "War on Terror", a strange war in which the enemy is criminalized if he defends himself and returns fire' (cited in Jones 2011: 9). And thus, it is no surprise that while the United States is fortifying their borders (Brown 2010), so too is Israel because the War on Terror is a universal war that besieges 'every democracy'. Such a sentiment was echoed by 
Chicago Rabbi Gary Gerson, who, in the immediate aftermath of the Al-Qaida 9/11 terror attacks in New York 2001, attempted to console a nation coming to terms with an act of terror upon the United States by committing that...

Humanity came apart in Lower Manhattan today, and each of us is wounded. We mourn the loss of our innocent... We are all Israelis now(Lubin, 2008).

In an effort to align the historical persecution of the Jewish community both biblically and specifically since the birth of Israel in 1949, 'we are all Israelis now' sought to share the burden of the contemporary 'western assertion of threat' against Islamic terror and bio-political self-importance. Here, Benedict Anderson's notion of the 'spectre of comparison' is apt because the comparison becomes an inverted telescoping of the idea of self and image through the gaze of a dominant culture (1998). For the Rabbi, this spectacle of terror represents a coalesce of identities, first as a Jew and second as an American citizen. Such an inversion is glaringly obvious when one examines the political rhetoric of America who fails to lament Israeli behaviour with any vigour. When the BBC reported the news that Israel had shelled a UN-run school in Rafah on 4 August, the US response was that it was 'appalled by the disgraceful shelling'. ${ }^{11}$ Thus, the conceptualization of a democracy or 'island of freedom' helps to further contextualize Israel's War on Terror within the wider frame of global terror. 'Located in a region controlled by military dictators, feudal kings and religious leaders, Israel should receive unreserved support from western liberal states interested in strengthening democratic values around the globe' (Gordon 2004) and as such, collateral damage is permissible when the life of the Palestinian is already lost 
before it even begins. With all this in mind, a third justification for the attack on Gaza, within the context of terror, democracy and victimhood linked to the political imagery, is the necessity to actively maintain a terror threat. In doing so, such a threat becomes a distraction from the basic fact that Israel is occupying Gaza and the West Bank. Traumatism, Derrida wrote in the wake of the $9 / 11$ terror attacks, is produced by the future, by the threat of the worst to come, rather than by an aggression that is 'over and done with' (Borradoria 2003: 97). Returning back to Eliot's 'Burnt Norton', 'time past and time future and the always present' also reflects the omnipresent threat of Palestinian terror, the worst to come. This threat is validated by the political rhetoric of the Israeli security discourse that is underpinned by a reassuring need to produce the iconography of a definable and defendable border.

\section{Visualizing catastrophe}

While the security wall makes the occupation ostensibly visible, specifically across western media and print journalism, other aspects of the occupation, namely, the systemic violence incumbent with the daily nature of life under occupation, are often less visible. Whereas images of the aftermath of Operation Protective Edge were made widely available across mainstream media and narrowcast through independent news agencies and social media platforms, each conflict only has a limited shelf-life in terms of media interest, the occupation of Gaza and the effect it has upon Palestinian life is largely unseen outside the frame of war. Like the previous Israeli military operations into Gaza, Operation Protective Edge was abound by the typical visual tropes associated with that specific political space; footage of Israeli aerial strikes from mid-range vantage points, Hamas rockets into Israel, the destruction of 
Gazan infrastructure and the gory politics of immediation ${ }^{12}$ related to Palestinian human life. While mainstream British media featured Palestinian ambulances shuttling across scarred landscapes and faces wrought with emotion, demonstrating how British broadcasting, on the whole, operate within an economy of 'taste and decency', Al Jazeera, as well as blogs, Twitter and Facebook across the Internet demonstrated with unrelenting pace, the horror of the Israeli strikes. The display of Palestinian bodies in all their visceral reality became the visual vehicle through which Palestinians have reliably, time and time again, sought to communicate their suffering at the hands of the Israeli State in an effort to engage a humanitarian discourse. As Lori Allen notes (2009: 161), the display of Palestinian death during clashes from the outbreak of the Second Palestinian intifada not only became a form of testimony but also constituted irrefutable proof of injustice.

In the opening page of her text, Martyr bodies in the media: human rights, aesthetics and the politics of immediation in the Palestinian intifada (2009), Allen describes how she is confronted by a series of graphic images by a Red Crescent Doctor 'where are the human rights... the person who cares about humanity, it would affect them, and they could judge... let the world see and it will do something'. This sentiment asserts in the midst of this montage of traumatic words and images that when presented with death and destruction, the world will act in defense of those who are subject to such disproportionate violence. The self-representation of the Palestinian, Allen writes, is lost in a self-mediated saturation of symbolic representations that focus on suffering, rather than them as politically active (2009), though of course the actions of the 2012 Freedom Rides, as well as the ongoing non-violent resistance during the Friday protests in the village of Bil'in, do seek to alter this perception. Yet for Gaza, the 
visibilities and circulation routes of knowledge related to Gaza are often limited in their contextual value. Critical of news authorship in the United States where the occupation is made visible through the repetition of readily understandable scenes and scenarios, Amahl Bishara (2012: 252) suggests that such mediations belong to the 'fantasy of immediation'. While the general American audience is led to imagine that they have the full story at their fingertips, meanings are not so transportable (Bishara 2012: 252). Writing in relation to anti-occupation demonstrations, Bishara notes that the significance of 'graffiti, quotes, and even oppositional postures' assumed during demonstrations [and recorded as images] shift when they are removed from the flow of events and recontextualized into news texts. ${ }^{13}$ Similarly, David Campbell has observed that during the bombardment of Gaza in 2008/2009 the coverage of the 'conflict' and its mediation by western press exacerbated the normal conditions of the occupation as temporal and exceptional. By outlining the tension between the international media's demand for access to a particular 'time and space', limited by the Israeli military censorship, a demand driven by immediacy, problems arise in how the media communicate the unseen and ever-present challenges faced by Palestinians.

As such, much of the journalistic approaches to the 2009 Operation Cast Lead were premised on the idea that the truth of the conflict could be found on the streets of Gaza, when access was eventually granted. With this in mind, Gianluca Panella's 2013 World Press award-winning series Black Out sought to challenge the immediacy and stock reportage of press-photography associated with conflicts, helping to reframe a space that is 'always on the brink'. Unpublished by the press the images were later presented as a twelve-photo collection that addresses the reality of life under 
occupation when fuel shortages, due to the Israeli imposed siege on the Gazan borders and harsh weather conditions forced the closure of Gaza's only power station, in November 2013. Taken without a flash, each image faithfully records the reality of a 21-hour Gazan blackout. Across the twelve images very little is visible, yet we know we are looking at an urban environment. The occasional light from a window, be that a torch or a candle, the red brake light of a car or just the natural light from the night sky breaks up the darkness and gives the images a sense of depth, slowly revealing the space within the frame. The homogeneity of the images reinforces the effect of abject darkness in a cityscape that should otherwise be bright and vibrant. Like a series of stills from Ridley Scott's neo-noir dystopian epic, Blade Runner (Scott,1982), the series communicates a sense of discomfort produced by the limiting darkness. As such, each building is black, each street devoid of any light except the odd flicker, informing the viewer that not only is there no electricity for the street lights, but no fuel for the cars; time and space has again stood still; the ongoing catastrophization of Gaza.

The assault on Palestinian infrastructure is nothing new, nor is the calculated management of Gazan life through systemic violence and 'deliberative targeting' of specific sites that 'places a logistical value on targets through their carefully calibrated, strategic position within the infrastructural networks that are the very fibre of modern society' (Gregory 2014). Thus, the 'symbolic' attack on the Gazan power station during Operation Protective Edge brought Gaza into darkness once more, while more long-term concerns arise as sewage plants and water pumps fail, refrigeration systems stop, and essential surgeries and life-support systems are interrupted. ${ }^{14}$ While the bombed out streets of permissible societies and 'non- 
democratic' spaces are repeatedly mediated to the point of visual exhaustion and juxtaposed with 'tribalistic displays' of public mourning and calls for revenge, Panella's images make apparent, through a visual strategy that effectively denies vision, how for Gazans the basic necessities of daily life are endlessly tied to the politics of life under occupation; fuel represents one of the most fundamental examples of this entanglement.

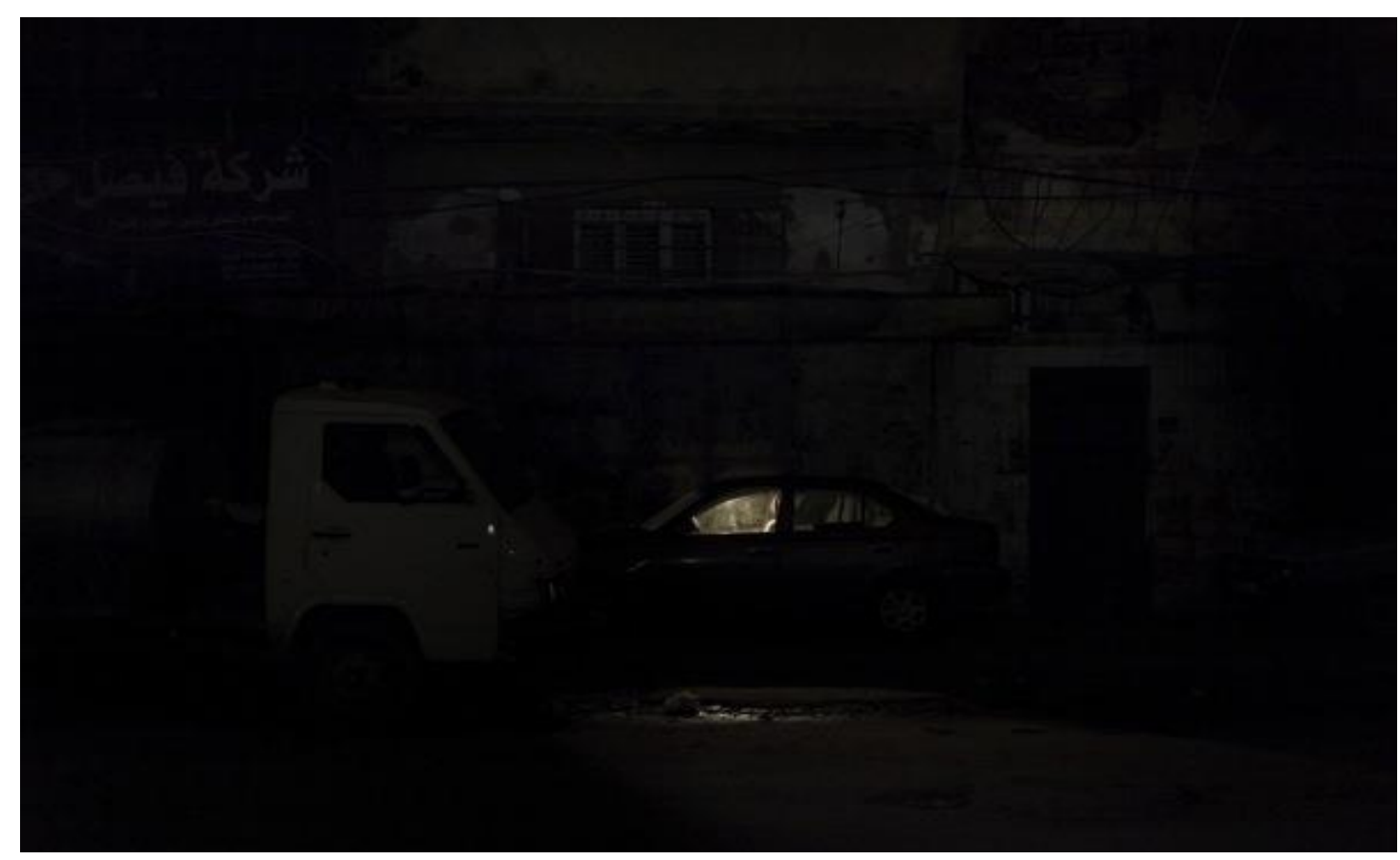

Figure 2: Gianluca Panella: 2013 A Gazan street, the only light is from the inside of a car.

Panella's images help us to think about life in a markedly different way to the typical images produced within or related to the highly politicized arena that is Gaza. Looking at the images the viewer enters a space that is devoid of atrocity, where the photographer oscillates between the investment in the capacity of documentary photography as a truth-telling medium for a specific moment frozen in time and the generality of a broader reading related to the asymmetric nature of the occupation. By not showing the act of violence itself, but rather alluding to it by depicting its 
consequence, the photographer engages our imagination. By addressing the problem of illumination and the difference between looking and seeing, Panella's images help communicate telling aspects of the occupation that are otherwise less visible. As such, his images function as a practical challenge for the viewer as much as they do a metaphor for Gazan life.

Similarly, albeit in the West Bank, the documentary photography practices of the Palestinian, Rula Halawani, also sought to challenge the paradigm of immediacy, commonly associated with press photography, creatively engaging with seemingly banal space, darkness and conflict. Photographing her hometown of Ramallah in 2002 during Operation Defensive Shield, Halawani spoke of her shock as the entire city had been transformed into a 'dark and scary place'. In an effort to communicate the darkness, Halawani took photos of the invasion and chose to exhibit the images as negatives in order to 'express the negation of our reality and of her people' (2012). Like the work of Panella, Halawani invites the spectator to enter the imaginative space of war and conflict by shifting the paradigm of spectatorship related to the Israel Palestinian conflict. Only by producing the images as she did, did Halawani feel it was possible to tell the larger story of just one 'specific period of the Palestinian experience of Israeli repression and destruction our lived reality' (2012). Halawani's images, like Panella's, are produced with a different representational intent and with a different spectatorial expectation. As documentary photographs, their images differ in what they are expected to communicate within the frame. As such, both photographers adopt a more nuanced and denotative approach to the visualizing occupation than conventional reportage. 
While Panella's images communicate the effect of the asymmetric nature of military and economic power besieged upon Gaza by Israel, the multifaceted effort to cripple the Palestinian economy with 'symbolic strikes' against the power station sits in tandem with the slow violence of military architectural planning and civilian/settler barricades that make up regime-made violence that operates below the typical visual sphere of perceptible violence. While Operation Protective Edge can be recognized as violence par excellence, a spectacular violence that was witnessed by the world, the population of Gaza has also endured the scandalous curtailment of access to food that was managed in such a way that it did not make the impact upon the Palestinian population overtly obvious. Rooted in the idea that the Palestinian should, in the words of Dov Weisglass, an adviser to then Israeli Prime Minister in 2008 Ehud Olmert, be put on a 'diet, but not to make them die of hunger' (Urquhart 2006). Such a tactic, the Israeli newspaper Ha'aretz stated, was an effort by Israeli officials to ensure Gaza's economy was 'functioning at the lowest level possible consistent with avoiding a humanitarian crisis' (Reuters 2011). However, the visualization of such is a question of politics, and politics, according to Jacques Ranciere, is a question of aesthetics, a matter of appearances (1999: 74). The very struggle over political perceptibility in Gaza is thus, I argue, as important as the struggle over the land, and in many cases intrinsically linked. This was most clearly enacted in Gaza during the 2005 'disengagement'. Examining the ways in which architecture is mobilized as a tactical tool within the unfolding struggle for Palestine, Hilal et al. noted that a varied mix of cultural and political perspectives informed the Israeli enforced evacuation of settlers from the strip. The evacuation and destruction of settler buildings was tied to the potential symbolic effect of images of Israeli architecture under Palestinian control. Prior to the evacuation of Gaza in 2005, Hilal et al. wrote that, 
The Israeli government decided that all settlement homes would be destroyed. One of the reasons stated in support of this decision was the government's wish to avoid the broadcast of what it felt were politically destructive images: Arabs living in the homes of Jews and synagogues turning into mosques. (2009)

The destruction of the buildings and settlements during the 2005 'disengagement' of Gaza was meant, amongst other reasons, to deny the function of this architecture as a political image; yet with all this in mind, I will, in my final section turn my attention to the Palestinian city of Hebron and the photography collective, Activestills.

\section{The politics of visibility: Boundaries in Hebron}

Established in 2005, Activestills operate outside the representational frame that largely shapes the political visibility of the occupation, working to challenge the prevailing representation that defines the Palestinian, as well as other peripheral communities within popular Israeli visual culture, such as print media and television. Whilst each photographer is a professional in his or her own right, or has the ability to demonstrate that they can operate at a professional standard, each member must also demonstrate a political commitment to challenge the inequality brought about by the occupation. Operating with a strong conviction that photography is a vehicle for social change and that the power of the image has the capacity to both shape public 
attitudes and raise awareness on issues that are generally absent from public discourse, the eleven members operate both in the West Bank and Gaza, as well as internationally.

Often excluded from the critical visibilities related to the occupation, Hebron exemplifies how the occupied Palestinian is ruled by the Israeli state but excluded from any of the citizenry rights granted to Israeli Jews, and to a lesser extent, Palestinians living within the Green Line. Those in the West Bank, who have lived under an occupation that has been in place for over 40 years, have seen a change in the ways in which the specific conditions and modes of power have changed in relation to their lived environment, both physically and in the culture through which it is regulated. The management of visibility within Hebron is controlled by the meaning of the events: events that take place and ordered by those who maintain control, namely, the Israeli military and Civil Administration. Due to the kidnapping of the three Israeli teenagers on the 13 June 2014, Hebron became visible if only for a short time, through the discourse of terror and savagery that was articulated into the Israeli narrative according to what needed to be seen, felt and thought. Immediately after the kidnapping of the Israeli teens, Hebron appeared within the media as a dark and remote Arab city, part of the web of terror that encircles Israel. A survey of all the major British newspapers during the raids and media outlets such as the BBC provide an identifiable set of images that reassuringly denote all the readable traits of western democracy in close proximity to violent and lawless population. IDF combatants, often in groups appear against arid landscape wearing the recognizable uniform of a 'liberating force' that underscore the relatable motifs of jingoism associated with the British- and US-led War on Terror. Such images reinforce Edward Said's (1994) 
analysis of Orientalist discourse that creates binaries between eastern and western cultures. The civilized and equipped 'Us' and inferior 'Other' is connotative of the image economy largely used within the press in response to the initial events in June. Like Rabbi Gerson in 2001, and that of the Israeli state throughout Operation Protective Edge, the language of victimhood and the images that support it are consistent with the 'information wars' that Said outlined as being waged by Israel in order to portray itself 'to Americans and Europeans as a victim of Islamic violence' (1994: xxi). Yet in what has already been discussed, and in what will follow, in the context of Israel-Palestine, visibilities are subject to power; those without power are caught in a struggle of perceptibility that is uneven and hard fought. Jacques Ranciere's assertion that 'politics is first of all a battle over sensible material' (2000) is thus very apt. The sensible order, in this specific case, the occupation, renders certain things visible, while others are removed or hidden. Specifically since the outbreak of the Second Palestinian intifada (2000), coupled with the increased presence of NGOs and advocacy roles of internationals, the processes of Palestinian mediation are, by and large, dependable on 'affect laden concepts of humanity' (Allen 2009: 163). As a result, the Palestinian is often subject to a pre-established 'field of perceptible reality' (Butler 2009: 64) that has already been established on their behalf, rather than with their consent or input. However, Activestills seek to make visible specific appearances, introducing a specific visibility into a field of experience, which in turn modifies the regime of the visible (Ranciere 1999: 29). This photographic practice, like the work of Panella, does not involve spectacle; instead it shows the subtlety of the occupation; the day-to-day reality, denying the scene and the objects within any sense of spectacle, both photographic practices invert the existing order of the seeable and the sayable. However, for those who live in Gaza, Ramallah and the 
Hebron and those who document the effect of the Israeli occupation in each space, all representation and experience will vary. While Gaza is under siege, the fragmentation of the West Bank through the settlement enterprise and related infrastructure to accommodate the Israeli settlers produced a different form of control over the space as much as it effects the visual representation of the occupation. As Eric Hazan writes, the case of Hebron is absurd and must be seen to be fully understood (2007). Activestills, either as a group or as individual members, have through their practice sought to make this absurdity visible. The collective negotiate a role whereby they work as news photographers selling their images to agencies that represent particular events, but more often each member operates as a documentary photographer and also an activist. Seeing a tangible relationship between the two roles each member returns again, and again to a particular place, operating above all with the aim of contributing to their own archive of photographs that builds a nuanced picture of the occupation.

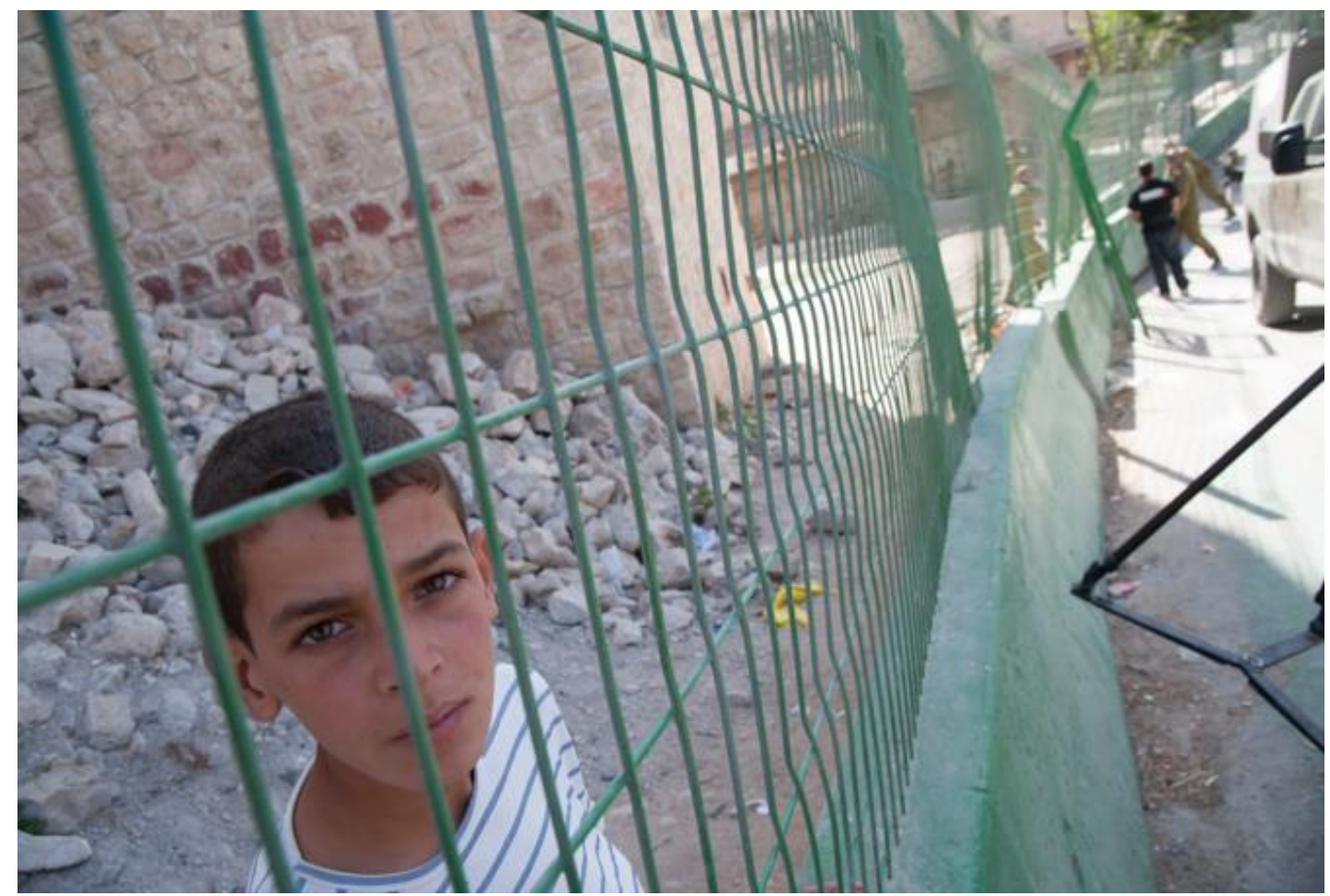

Figure 3: Activestills: Palestinian boy looks through a barrier dividing one of 
Hebron's segregated roads where Israelis may drive, but Palestinians must walk on the side, November 2013.

A small Palestinian boy looks through a barrier dividing one of Hebron's segregated roads. For the Palestinian, the fence restricts and corrals their movement, limiting their passage to a narrow channel filled with rubble, dirt and a sequence of steps that make movement for the elderly and infirm difficult. The division of the street reflects the inequality of the occupation; the Israeli-only side is wide enough for traffic to flow both ways. The photo is one of fourteen images taken in a series by the American born, Israeli-based photographer, and member of Actvestills, Ryan Rodrick Beiler during one of his regular trips to the Occupied Palestinian Territories. Taken from the Israeli-only side of the division, the boy is framed from behind the green metal fence that limits his movement. The green metal fence orders the image and our visibility; from the position of the photographer, the viewer is ostensibly looking in on the boy, looking in as a citizen, upon a subject of the occupation. Conversely, the boy is looking back, his gaze directly meets the lens and thus he addresses the spectator in a candid fashion. The young boy addresses the camera with a look of recognition, a possible recognition for the potential of the camera to make visible his plight. Such an exchange has been noted by Arella Azoulay as the 'civil contract of photography', a contract that is bound by the 'partnership of solidarity' (2008). Azoulay suggests that this 'contract' anchors the spectator in a civic duty towards the photographed person. Whilst the young boy is most acutely in focus, the fence is given the greatest economy. Cutting across the centre of the photograph, and blurring out of focus, the sense of depth afforded to the image by the fence takes our gaze to the rear of the image where men, presumably IDF soldiers continue to mark out the improvised boundary. 
Hebron is the second largest city in the West Bank and the only Palestinian city with a settlement in the middle of it. ${ }^{15}$ The Israeli settlement of Hebron is concentrated in and around the Old City, which traditionally served as the commercial centre for the entire West Bank. A report commissioned by the Minister of Development Cooperation in the Netherlands, B'Tselem and the Israeli Association of Civil Rights notes that the 'authorities [Israel] have created a long strip of land that partitions the city into southern and northern sections and is forbidden to Palestinian vehicles with some parts of the strip completely closed to Palestinian pedestrians'. The Israeli settlers, on the other hand, are allowed to move about freely in these areas. Restriction on movement escalated in the city after the 1994 massacre of Muslim worshipers in the Tomb of the Patriarchs, carried out by the Israeli settler Baruch Goldstein.

After the Oslo Accord in 1995, agreements were made between Israel and Palestine to divide the city in two: $\mathrm{H}-1$ and H-2. The former comprised an 18 square kilometres zone where most of the city's Arab residents live (about 115,000) and was given over to the control of the Palestinian Authority. The latter, H-2, fell under direct control of the Israeli army; a space no bigger than 4.3 kilometres, the Israelis became responsible for some 35,000 Palestinians. The rationale was for both parties to work in cohesion and ensuring that 'security responsibility will not divide the city... with both sides sharing the mutual goal that movement of people, goods and vehicles within, and in and out of the city will be smooth and normal, without obstacles or barriers' (Feuerstein 2007: 11).

In 2000 the Second Palestinian intifada (Al-Aqsa intifada) broke out, resulting in intensified fighting, and the impact upon Hebron and the Palestinian residents resulted in widespread curfews and the implementation of flying checkpoints. Since the 
outbreak of the Second intifada, the Old City, the commercial centre and the service routes via the north-south traffic artery are still today out of bounds for Palestinian residents. Restrictions on Palestinian movement are mapped by a constellation of staffed checkpoints and physical roadblocks. In August 2005, the OCHA counted 101 physical obstructions of different kinds in H-2 (Feuerstein, 2007: 20). The most notable and documented act of boundary manipulation was the forced closure of Hebron's main commercial centre, Shuhada Street, reducing the city centre into a ghost town.

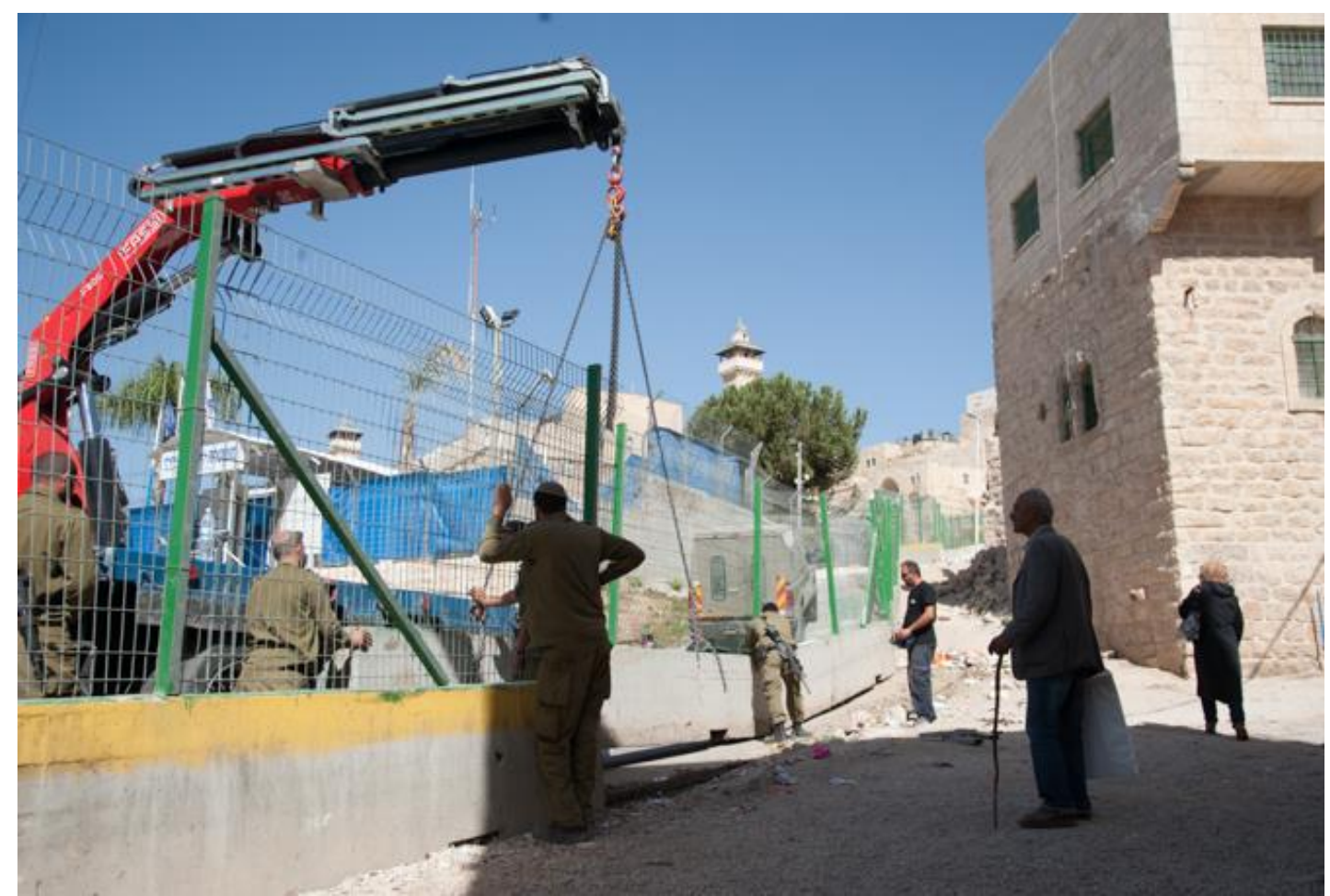

Figure 4: Activestills: An old Palestinian man watches on as IDF personal cut off what was previously Palestinian road with an $8 \mathrm{ft}$ high mental and concentre boundary, November 2013.

Yet Beiler's images are atypical of much of the representational practices related to Israel-Palestine. Whilst a great deal of attention is paid to the stark materiality and scale of the $8 \mathrm{~m}$ high concrete slabs of the Israeli enforced separation barrier, Beiler, 
as well as those who make up the Activestills collective, use documentary photography to 'claim the frame' (Apel 2012: 6) for those that lack visibility and voice. Noting Susan Sontag's assertion that the rise of photojournalism has contributed to the cultural ubiquity of images of atrocity, Sontag suggests that the 'shock image' is part of the normality of a culture in which shock has become a leading stimulus of consumption and sources of value (2003: 23), one that helps to sell news stories or to generally draw in attention. Focusing on border and boundary fortification within an Israeli Palestinian context, the 'shock' in relation to visual reportage is most commonly attributed to the enormity of the Israeli separation barrier that lines the West Bank perimeter. The barrier, which once functioned as an effective and powerful image within the media-economy of the conflict, 'one resonating within a western historical imagination still engaged with the unresolved memories of its colonial and Cold War legacies' (Weizman 2007: 171) has been lessened as time has passed. Meanwhile on a domestic level, Eyal Weizman notes that the barrier represents an effort by the Israeli State to produce a reassuring iconography of a border within a liquid geography (2007: 228), a liquescence that is made visible through Beiler's photography.

Against the dominant motifs and representations of the occupation one can use Ranciere's examination of the role of politics and aesthetics as a framework in which to think through Beiler's practice and to enable the drawing out of some general points applicable to the issue of political visibility and the redistribution of visuality. Returning to Ranciere's notion that 'politics is a question of aesthetics, a matter of appearances' (1999: 74), and the notion that regimes of visibility between politics and aesthetics concerning what is possible to see and how that visibility is constructed are closely aligned with the distribution of power, Beiler's effort to rearrange the existing 
'distribution of the sensible', that is the laws that prescribe what can be heard and seen in a specific political and social constellation, necessitates a different set of artistic strategies than those typical of photojournalism and documentary practices common within the region. As such, the photographer denies the spectacle of disaster par excellence or typical visual tropes that have been consistent within the region. ${ }^{16}$ In the Palestinian city of Hebron, as is the case across the Occupied Territories, the relationship between politics and the distribution of sovereign power are negotiated on a daily basis. With this comes the question of visibility, representation and frame, because as Mieke Bal notes, seeing is innately political (2003). Thus, the visibility of the occupation is contingent on how political action is framed and translated into images. Anti-occupation practices are thus dependent on making visible what is not commonly seen.

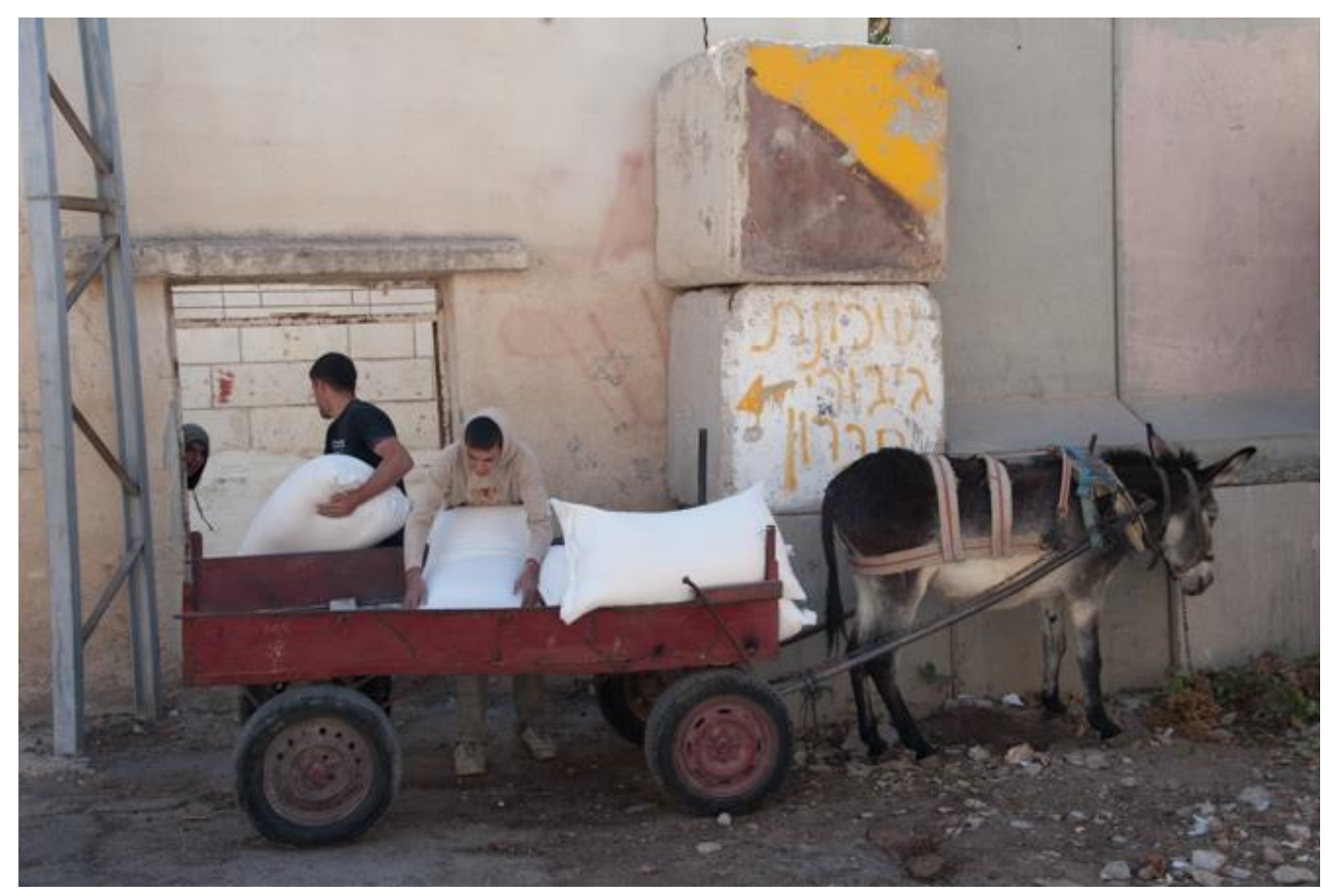

Figure 5: Activestills: Three Palestinian men unload food from a donkey drawn cart, November 2013. 
In the final photos in this essay, three Palestinian young men are seen unloading a donkey cart carrying sacks of ingredients for use in a local shop, located in the H2 section of Hebron. As the last image in the series, the photo is anomalous to the other thirteen images. Scribbled on the wall, right of the door in yellow paint reads 'the neighborhood of Hebron's heroes' in Hebrew. A reference to the nearby Qiryat Arba settlement, established in 1970, a crudely drawn Star of David supplements the graffito. This photo, like the work of Panella and Halwani draws us in, it requires contemplation, helping us to think about the effect and processes of the occupation in different ways, opening up new conversations about the implications of living under occupation, as well as its precarious nature. The image is embedded within a system of visibility that governs the status of the bodies represented and supports the kind of attention they merit (Ranciere 2009: 99). Each object in the frame represents some aspect of asymmetrical nature of the occupation. First, due to flying checkpoints, which the half yellow and graffiti sprayed concrete blocks represent, the Palestinian is subject to ad hoc boundary movements, and as such, variable restrictions between differing administrative zones. Second, the restrictions on automotive vehicles limit Palestinian mobility to either foot or cart in the Israeli administrated zones, while Israeli settlers are allowed the freedom to drive. As such the young men are subjects of the occupation; they are both inside and outside the law and represent the relationship between Israel as an occupying society and the occupied Palestinian population that has been described as a condition of 'inclusive exclusion' (Ophir and Hanafi in Hanafi 2009) through which Palestinians are ruled by the Israeli state but excluded from its protection. Moreover, the donkey and cart, the stark materiality of 
the wall and the Hebrew writing all attest to the Palestinian's spatial indistinction everything that is visible in the frame has been imposed upon them.

\section{Conclusion}

In summary one may argue that visibility is subject to power, those who are without visibility are the least likely to be heard or seen. This notion was clearly demonstrated during Operation Protective Edge whereby the Israeli media machine quickly galvanized the rhetoric of a democratic nation responding to Islamic terror. As such, the Palestinian was framed through a nationalized way of seeing, grounded in the dominant Israeli discourse of national security and victimhood. Yet for events outside of Operation Protective Edge the everyday realities of the occupation are often unseen. While the representational cache of the occupation is drawn from a stock of easily identifiable images bound by a specific event such as military operations, that produce images of Palestinian destruction and death, the ongoing catastrophization of Gaza is much less visible, especially outside the frame of a newsworthy event. However, Panella and Activestills alongside conventional press photography contribute to a growing archive that details the varying pace of regime-made disaster inflicted upon the Gaza and the West Bank. As such, it might be suggested that each form of image production, photojournalism and more nuanced documentary photography compete for a meta-physical representation of the greater whole. Each form of visibility making addresses a different type of experience for those living with the Israeli occupation, making visible varying types of violence that are produced at different speeds yet share the same ultimate goal - to make life under occupation unbearable. 
Visibility is based on a relationship through the means of production and the reception of what is being mediated. Images like those discussed above are also subject to a debate over how what is being visualized is also being seen. It is with this in mind Vanessa Joan Muller's belief that some images, specifically photographs can communicate an atmosphere, a sensory experience that is not visible, but redolent in the production, one that channels the focus away from what is being represented, towards the 'how' of its perception is pertinent (2011: 4). In documentary photography examples presented above, we are asked to think about how this has come to be as much as to what it is we are being presented with. Thus, by looking at these photos in relation to others, including press photography and counter visibilities produced by Palestinian production companies like MediaTown help to communicate the 'space in between', communicating the everyday aspects that maintain a society on the brink.

\section{References}

Allen, L. (2009), 'Mayer bodies in the media: Human rights, aesthetics and the politics of immediation in the Palestinian Intifada', American Ethnologist, 36:01 pp. $161-80$.

Anderson, B. (1998), The Spectre of Comparisons: Nationalism, Southeast Asia and the World, London: Verso.

Apel, D. (2012), War, Culture and the Contest of Image, New York: Rutgers University Press. 
Arnaout, A.-R. (2014), 'From shield to edge: How Israel names its military ops', Anadolu Agency, 8 July, www.aa.com.tr.en/world/355946-from-shield-to-edge-howisrael-names-its-military-ops. Accessed 1 August 2014.

Azoulay, A. (2005), 'The darkroom of history', Journal of Theoretical Humanities, 10:03, pp. 57-77. (2008), The Civil Contract of Photography, London: Zone.

Bal, M. (2003), 'Visual essentialism and the object of Visual Culture', Journal of Visual Culture, 02:01 pp. 5-32.

Bishara, A. (2012), Back Stories: U.S. News Production and Palestinian Politics, Stanford: Stanford University Press.

Bhungalia, L. (2010), 'A limited territory: Gaza executive discretion, and sanctions turned humanitarian', Geojournal, 75:04 pp. 347-57.

Borradoria, G. (2003), Philosophy in a Time of Terror: Dialogues with Jurgen Habermas and Jacques Derrida, Chicago: Chicago University Press.

Brown, W. (2010), Walled States, Waning Sovereignty, Cambridge: MIT Press.

Butler, J. (2009), Frames of War:When Life is Grievable, New York: Verso. 
Campbell, D. (2009), 'Constructed Visibility: Photographing the Catastrophe of

Gaza', The Aesthetics of Catasthrope, Chicago, pp. 1-45 (Unpublished)

https://www.david-campbell.org/wp-content/documents/Constructed_Visibility.pdf.

Accessed 3 September 2014

Couldry, N. (2000), The Place of Media Power: Pilgrims and Witnesses of the Media Age, London: Routledge.

Eliot, T. (1969), Four Quartets, London: Macmillian.

Faulkner, S. (2009), 'What are you looking at', Programma, 01:01, pp. 128-35.

Feuerstein, O. (2007), 'Ghost town: Israeli's separation policy and forced evection of Palestinians from the centre of Hebron', Development of Coordination, B'tselem and The Association for Civil Rights in Israel, Jerusalem.

Guénoun, S., and Kavanagh,J. (2000), 'Jacques Ranciere: Literature, Politics, Aesthetics: Approaches to Democratic Disagreement', SubStance, 29:02, pp. 3-24.

Gordon, N. (2008), Israel's Occupation, California: California University Press. (2004b), 'Most Israelis don't believe it (or support it): The only democracy in the Middle East?', Counterpunch, 3 Febuary, www.counterpunch.org. Accessed 5 October 2013. 
Gregory, D. (2014), 'Darkness deceding', Geographical Imaginations, 29 July, www.geographicalimaginations.com. Accessed 30 July 2014.

Halawani, R. (2012), 'Arts and politics in Palestine through my photographs', ArteEast, 8 March, www.areteast.org/2012/03/08/arts-and-politics-in-palestinethrough-mymphotographs. Accessed 21 July 2014.

HARDtalk: Dr. Mads Gilbert: Life as a Doctor in a Gaza Hospital (2014,United Kingdom: BBC).

Hanafi, A. O. (2009), The Power of Inclusion Exclusion, Michigan: MIT University Press.

Hazan, E. (2007), Notes on the Occupation, New York: The New Press.

Hilal, S., Petti, A. and Weizman, E. (2009), 'The future archaeology of Israel's colonization', Afterall, 20.

http://afterall.org/journal/issue.20/future.archaeology.israels.colonisation. Accessed 5 February, 2013

Jones, C. (2011), 'Shooting Gaza: Israel’s visual war', Human Geography, 04:01. Levy, E. (2014), 'IDF preparing for Siege on Hebron', Y net news, 15 June, www.ynetnews.com. Accessed 15 June 2014. 
Lubin, A. (2008), 'We're all Israelis now: The politics of colonial comparisons', South Atlantic Quartley, 107:04 pp. 671-90.

Mckee, M. F. and Feher, M. (eds) (2007), Nongovernmental Politics, New York: Zone.

Mclagan, M. (2007), 'The Architecture of Strategic Communication: A profile of Witness'.

Muller, V. J. (2011), 'Seeing, not looking', in N. Schafhausen (ed.), All About US, Germany Sternburg Press.

Ophir, A. (2009), 'Reflections on Gaza from Tel Aviv', Znet, http://www.zcommunications.org/znet/viewArticle/20230. Accessed March 2010

Said, E. (1994), Orientalism, New York: Vintage Books.

Scott, Ridley (1982), Blade Runner, Hollywood: The Ladd Company.

Shavit, A. (2004), 'Survival of the fittest: An interview with Benny Morris', Ha'aretz, 16 January, www.haaretz.com. Accessed 20 July 2014.

Sontag, S. (2003), Regarding the Pain of Others, London: Penguin. 
Spencer, R. (2014), 'Israel-Gaza conflict: Netanyahu compares Hamas rocket attacks to the Blitz', The Telegraph, 24 July, www.telegraph.co.uk. Accessed 24 July 2014.

Ranciere, J. (1999), Disagreement: Politics and Philosophy, Minnesota: University of Minnesota Press.

(2009), The Emancipated Spectator, London: Verso.

Reilly, J. (2014), 'Israeli official calls for concentration camps in Gaza', The daily Mail, 4 August, www.daileymail.co.uk. Accessed 4 August 2014.

Reuters (2011), 'WikiLeaks: Israel aimed to keep Gaza on the brink of collapse', Ha'aretz, 5 Janaury, www.haaretz.com/diplomacy-defense/wikileaks-israel-aimed-tokeep-gaza-on-the-brink-of-collapse-1.335354. Accessed 17 July 2014.

Tawil-Souri, H. (2014), 'The technological end between the "Inside" of Gaza and “Outside" of Gaza', September, http://www.7iber.me/2014/09/the-technological-endbetween-the-inside-of-gaza-and-the-outside-of-gaza/. Accessed 3 October 2014.

Urquhart, C. (2006), 'Gaza on the brink of implsion', The Guardian, 16 April, www.theguardian.com/world/2006/apr/16/israel. Accessed 3 July 2014.

Weizman, E. (2007), A Hollow Land: Israel's Architecture of Occupation, Michigan: Verso. 


\section{Contributor details}

Gary Bratchford is a researcher at the MIRIAD research centre, Manchester Metropolitan University, UK. He is a board member of the International Sociology Associations' Visual Sociology Group and sub editor of the Visual Sociology Newsletter. His doctoral research is on 'Visual Activism in Israel and the Occupied Palestinian Territories'. His recent publications include articles on Image research and Palestinian visibility, published in the open access British Library E-book Looking At Images: A Researchers Guide.

Contact:

MIRIAD, Manchester Metropolitan University, The Righton Building, Cavendish Street, Manchester, M15 6GB, UK.

E-mail: g.bratchford@mmu.ac.uk

Notes

${ }^{1}$ Taken from Ariella Azoulay's The Darkroom of History (2005) the Fourth Geneva Convention (1949), regarding the status of an occupation, a territory is considered occupied when it is de facto under the authority of the hostile army (Fourth Geneva Convention, Paragraph 42). The occupation of inhabited territory, then, is always temporary, and not only because the regulations point to the horizon of its conclusion - 'when peace shall be made' - but because of the presence in the occupied territory of a population that cannot be occupied. 'It is forbidden', says Paragraph 45, 'to force the inhabitants of the occupied territory to swear allegiance to the hostile ruling power (Azoulay 2005: 74). 
${ }^{2}$ During operation Cast Lead, 2009, the first two weeks of the conflict, international journalists were banned from entering the Gaza Strip.

${ }^{3}$ A Bedouin Palestinian died during rocket fire from Gaza; however, Bedouin communities within Israel are denied basic services or recognized as citizens of Israel, yet it was reported that Israel attempted to claim the loss for their own statistics. For more information, http://972mag.com/israels-bedouin-civilians-in-deathalone/93965/.

${ }^{4}$ Figures accessible from:

http://www.amnesty.org/en/library/asset/MDE15/023/2014/en/c931e37b-a3c2-414fb3a6-a00986896a09/mde150232014en.pdf.

${ }^{5}$ Examples of which can be found here: http://visualizingpalestine.org.

${ }^{6}$ The video is accessible here: https://www.youtube.com/watch?v=jBEFBixO1ck.

${ }^{7}$ An area more commonly known as the West Bank, Judea and Samaria are biblical references to the land.

${ }^{8}$ The full interview can be accessed here:

https://www.youtube.com/watch?v=H903Ecuuluk.

${ }^{9}$ Information related to deaths and causalities related to the above mentioned operations can be found at www.BTselem.org.

${ }^{10}$ For more on this, see Gil Hochburg's forthcoming book about the visual politics of the Israeli Palestinian conflict titled Visual Occupations: Violence, Visibility \& Visuality at a Conflict Zone. Hochburg suggests that the visual economy of the Israeli Palestinian conflict can be understood as the outcome of an interchange between several competing visual fields: the state-controlled (Israeli) visual field; the countervisual fields produced in direct response to military occupation from within and outside the occupied territories; and the global visual field produced by various 
different networks e.g. Human Rights Organization (HROs) and disaster tourism. In the context of this article, the focus is on 'eligible' life in direct relation to Israeli life and, by proxy, cultured and democratic Western life which Israel stands in for, within the middle-east. Within an HRO framework, Lori Allen's suggests that the Palestinian body has been used as a vehicle to support HRO funding, often reproduced in a limited cache of representations, either as a victim or as helpless (see Allen's The Rise and Fall of Human Rights [2012]).

${ }^{11}$ http://www.bbc.co.uk/news/world-middle-east-28635031.

${ }^{12}$ Lori Allen writes that immediation is a particular approach to making political claims that foregrounds natural life as the ground of a particular set of rights. Specifically, Allen and I, in the context of this paper adopt this notion in relation to the power dynamic of visibility relation to the occupation and the representation of the 'Palestinian'. Thus, the linking of human rights, visuality and affect are common to Palestinian political and social life, structured around an ideal of 'immediation'. Although human rights (an ideology, language and system of institutions), visuality (a sensory perception, aesthetic system, and range of image objects produced and circulated in large part by broadcast media) and affect (a way of feeling, experiencing and reacting to experiences) are distinct dimensions, together they make up a 'politics of immediation'. Adapted from Mazzarella (2006) .

${ }^{13}$ For a discussion of this, see Amahl A. Bishara (2012: 250-55).

${ }^{14}$ For more on this, see Human Rights Watch and their report on the wide-spread impact of the Gaza power plant attack:

http://www.hrw.org/news/2014/08/10/gaza-widespread-impact-powerplant-attack.

${ }^{15}$ Other than East Jerusalem, which Israel annexed immediately following the 
occupation, in 1967.

${ }^{16}$ For an extended discussion of this, see Amahl A. Bishara (2012: 167-96). 